\title{
Comment on "Dust provenance in Antarctic ice during glacial periods: From where in southern South America?" by D. M. Gaiero
}

\author{
B. Delmonte, ${ }^{1}$ R. J. Delmas, ${ }^{2}$ and J.-R. Petit ${ }^{2}$ \\ Received 26 September 2007; accepted 6 March 2008; published 22 April 2008.
}

Citation: Delmonte, B., R. J. Delmas, and J.-R. Petit (2008), Comment on "Dust provenance in Antarctic ice during glacial periods: From where in southern South America?' by D. M. Gaiero, Geophys. Res. Lett., 35, L08707, doi:10.1029/ 2007GL032075.

[1] The geographic origin of wind-carried mineral dust in East Antarctica is a key issue for paleoclimate research and a fundamental input for GCM simulations. Although the provenance of mineral aerosol is almost established for the Last Glacial Maximum (LGM) and some late Quaternary glacial times, the dust source(s) during interglacials are still unidentified. In this respect, Gaiero [2007]: "Dust provenance in Antarctic ice during glacial periods: From where in southern South America?" provides a potential key for the solution of the interglacial dilemma and allows revisiting some previous interpretation of Antarctic dust data.

[2] Electron microscope microparticle investigations [Gaudichet et al., 1992; De Angelis et al., 1992] suggested southern South America as dominant mineral dust supplier to East Antarctica (Vostok and Dome C) during LGM. Chemical data [Delmas and Petit, 1994] supported this hypothesis, showing an agreement between Antarctic dust and high-altitude subtropical Andean deserts. Grousset et al. [1992] started a new era for dust source investigations in Antarctica by providing the first isotopic $\left({ }^{87} \mathrm{Sr} /{ }^{86} \mathrm{Sr}\right.$ and ${ }^{143} \mathrm{Nd} /{ }^{144} \mathrm{Nd}$ ) measurements on Antarctic dust from the last glacial. Indeed, that work was a prelude for a number of following isotopic studies expanding the sampling back to older glacial times [e.g., Basile et al., 1997] and to different drilling sites within the Antarctic Plateau [e.g., Delmonte et al., 2004a, 2004b]. The good isotopic matching between Antarctic glacial dust and Argentinean loess (Figure 1) corroborated the idea of a dominant South American origin for Antarctic dust during late Quaternary glacial ages. By pushing mass spectrometry to extreme thresholds, some data for the Holocene and MIS 5.5 are also available today [Delmonte et al., 2007]. Despite the relatively large error of measurements due to the very small amount of dust extracted from interglacial ice ( $20 \mu \mathrm{g}$ on average), Holocene and MIS 5.5 dust displays an overall isotopic signature significantly less radiogenic in Neodymium than glacial dust (Figure 1) and definitely falling outside the southern South American isotopic field constructed on the basis of

\footnotetext{
${ }^{1}$ DISAT, Department of Environmental Sciences, University MilanoBicocca, Milano, Italy.

${ }^{2}$ Laboratoire de Glaciologie et Géophysique de l'Environnement, CNRS-Université Joseph Fourier, UMR 51230, St Martin d'Hères, France.

Copyright 2008 by the American Geophysical Union. 0094-8276/08/2007GL032075
}

dust and sediment samples collected at latitudes higher than $32^{\circ} \mathrm{S}$ [Delmonte et al., 2004a].

[3] Delmonte et al. [2007] could not explain the dissimilarities between glacial and interglacial dust as environmental changes occurred within a given source as consequence of weathering and/or pedogenesis, as these processes potentially affect the $\mathrm{Rb}-\mathrm{Sr}$ rather than the $\mathrm{Sm}-\mathrm{Nd}$ system. Therefore, they considered basically two possibilities. One is still a dominant South American provenance but from a region not captured by the sampling adopted for building their isotopic field, in other words from lower latitudes. A second possibility is a relative weakening of the South American source during warm times and a supplementary contribution from other continents. In this respect a fundamental help came from Revel-Rolland et al. [2006] who documented for the first time the isotopic signature of Eastern Australian fine-grained sediments and dust. Some of their data came very close to interglacial Antarctic dust, suggesting a possible contribution from Australia during warm stages. Yet, the problem was not definitely solved, as a $\mathrm{Sr}$ isotopic shift between interglacial Antarctic dust and Australian data still existed and it could not be properly explained.

[4] Today, new geochemical data from Patagonian materials [Gaiero et al., 2007] and Argentinean loess [Smith et al., 2003] are accessible. In addition, Gaiero [2007] makes clear that Patagonia and the Puna-Altiplano Plateau (P.A.P.) area represent the active source regions for dust exported from South America and transported long-range during late Quaternary glacial ages, as for present-day conditions [Prospero et al., 2002]. The author concludes that a direct transport of mineral dust from these two areas to Antarctica occurred during Pleistocene glacial times.

[5] By emphasizing the role of the these two source regions as a major source of impurities for the upper Antarctic Plateau during glacial periods, some assumptions of previous studies which rather favoured Patagonia and its continental margin can be changed. Indeed, this shift toward more continental Andean areas could induce major changes in the bulk composition of the aerosol deposits in Antarctic snow during glacial times, as a more continental aerosol source would rather contain aged calcium salts, in particular $\mathrm{CaSO}_{4}$, locally formed by the reaction of volcanic $\mathrm{SO}_{2}$ with sedimentary $\mathrm{CaCO}_{3}$. Moreover, S-isotope measurements on the Vostok core [Alexander et al., 2002, 2003] support the hypothesis of an additional volcanic sulfate component in the sulfate budget of Vostok ice for glacial conditions. In the light of Gaiero [2007], we suggest this source of sulfate could be located in the Patagonian/Puna-Altiplano regions.

[6] Assuming Gaiero's [2007] hypothesis as realistic, this work provides a likely solution to the interglacial dust 


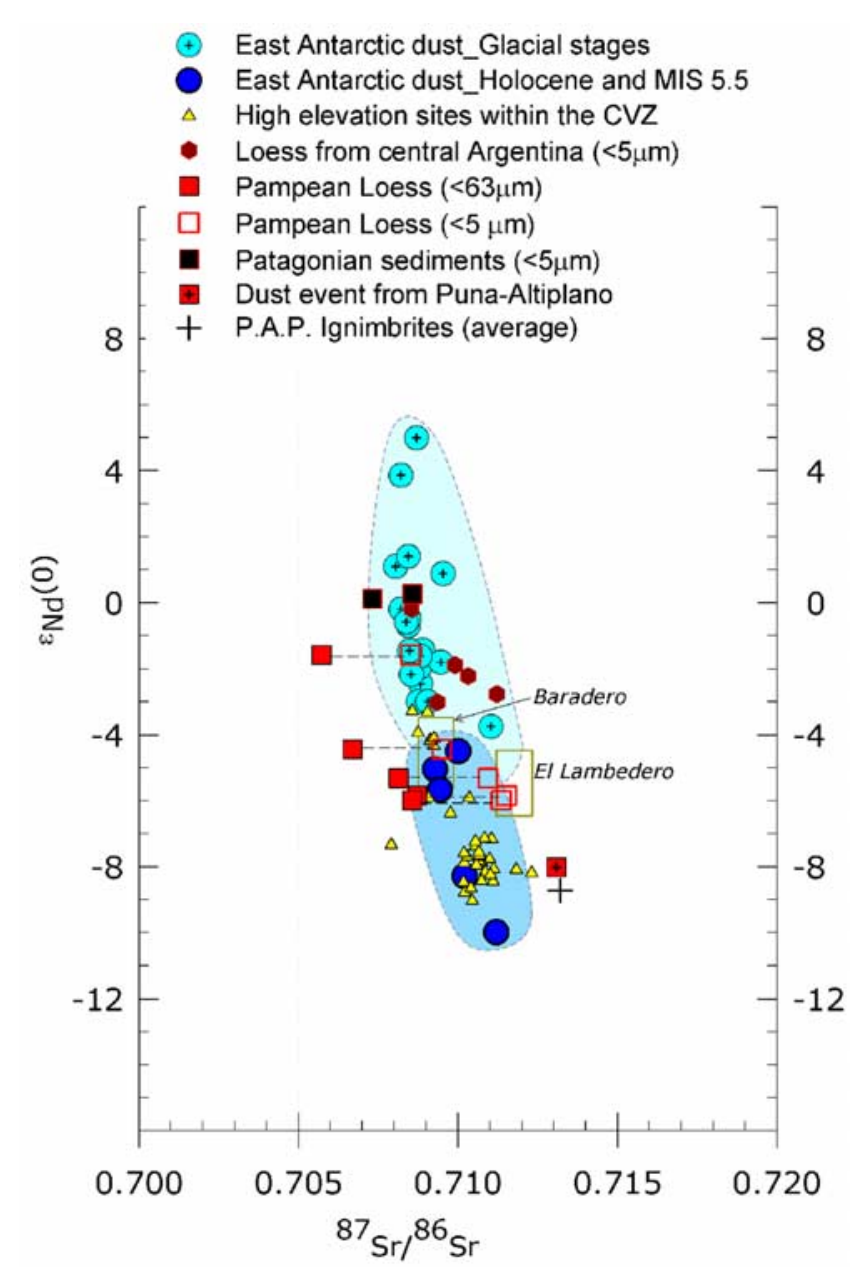

Figure 1. Strontium and Neodymium isotopic composition of East Antarctic eaolian dust from glacial [Basile et al., 1997; Delmonte et al., 2004a, 2004b] and from interglacial (Holocene and MIS 5.5) [Delmonte et al., 2007] stages. Antarctic ice core dust is compared to Patagonian sediments (<5 $\mu \mathrm{m})$ [Gaiero et al., 2007; Delmonte et al., 2004a], to loess samples from Central Argentina $(<5 \mu \mathrm{m})$ [Delmonte et al., 2004a] and to Pampean loess samples $\left(31-36^{\circ} \mathrm{S}\right)$ [Gaiero et al., 2007]. For these latter, both the $<63 \mu \mathrm{m}$ value and the relative value for the $<5 \mu \mathrm{m}$ size fraction (calculated taking into account the ${ }^{87} \mathrm{Sr} /{ }^{86} \mathrm{Sr}$ isotopic shift of 0.0028 units suggested by Gaiero et al. [2007]) are reported. The boxes roughly define isotopic fields for Baradero and El Lambedero areas taken from Smith et al. [2003]. The average value for P.A.P. ignimbrites [Gaiero et al., 2007, and references therein] and the isotopic composition of aeolian dust from the P.A.P. [Delmonte et al., 2004a] are also reported. These two values show the lowest $\varepsilon_{\mathrm{Nd}}(0)$ values and lie very close to the interglacial dust isotopic field. Bibliographic data (data source:http://georoc.mpchmainz.gwdg.de/georoc/Entry.html) from different source rocks located at high-elevation sites within the Central Volcanic Zone between $\sim 21^{\circ} \mathrm{S}$ and $\sim 23^{\circ} \mathrm{S}$ (corrected for ${ }^{87} \mathrm{Sr} /{ }^{86} \mathrm{Sr}$ size fractionation of a factor $\sim 0.0028$ as suggested by Gaiero et al. [2007]) are also reported for comparison. problem. During the Holocene and MIS 5.5 (around 120130 kyr B.P.) the Patagonian source was reduced with respect to glacial stages, in particular because of diminished glacial activity. Conversely, the high altitude areas from the Andean Puna-Altiplano experienced periods of enhanced aridity, as shown for instance by the Salar de Uyuni core from Bolivia [Fritz et al., 2004]. In the hypothesis of a bipolar mixing between the two south American sources, during interglacial stages the high-altitude subtropical dust source can be thought to have been relatively more important for the East Antarctic plateau than during glacials, and conversely for the Patagonian source. Indeed, a remarkable isotopic matching exists between interglacial dust in Antarctica and high-altitude ( $>\sim 5500 \mathrm{~m}$ a.s.l.) subtropical sites from the Central Andean Volcanic Zone $\left(21-23^{\circ} \mathrm{S}\right.$, bibliographic data corrected for the $\mathrm{Sr}$ isotopic fractionation as suggested by Gaiero [2007]). Interestingly, an independent support to this hypothesis has been recently provided by Siggaard-Andersen et al. [2007], that showed Holocene Lithium enrichment factor values from the Epica-Dome $\mathrm{C}$ ice core that are very similar to those measured in an ice core from Bolivia (Nevado Illimani core) by Correia et al. [2003]. These evidences must be confirmed by additional data; however, overall they point to a connection between high-elevation subtropical Andean deserts and the high Plateau of Antarctica during the Holocene and Quaternary interglacial times.

\section{References}

Alexander, B., J. Savarino, N. I. Barkov, R. J. Delmas, and M. H. Thiemens (2002), Climate driven changes in the oxidation pathways of atmospheric sulfur, Geophys. Res. Lett., 29(14), 1685, doi:10.1029/2002GL014879.

Alexander, B., M. H. Thiemens, J. Farquhar, A. J. Kaufman, J. Savarino, and R. J. Delmas (2003), East Antarctic ice core sulfur isotope measurements over a complete glacial-interglacial cycle, J. Geophys. Res., 108(D24), 4786, doi:10.1029/2003JD003513.

Basile, I., et al. (1997), Patagonian origin of glacial dust deposited in East Antarctica (Vostok and Dome C) during glacial stages 2, 4 and 6, Earth Planet. Sci. Lett., 146, 573-589.

Correia, A., et al. (2003), Trace elements in South America aerosol during 20th century inferred from a Nevado Illimani ice core, eastern Bolivian Andes (6350 m asl), Atmos. Chem. Phys., 3, 1337-1352.

De Angelis, M., et al. (1992), Source of continental dust over Antarctica during the last climatic cycle, J. Atmos. Chem., 14, 233-244.

Delmas, R. J., and J. R. Petit (1994), Present Antarctic aerosol composition: A memory of ice age atmospheric dust?, Geophys. Res. Lett., 21, 879882 .

Delmonte, B., et al. (2004a), Comparing the Epica and Vostok dust records during the last 220,000 years: Stratigraphical correlation and provenance in glacial periods, Earth Sci. Rev., 66, 63-87.

Delmonte, B., et al. (2004b), Dust size evidence for opposite regional atmospheric circulation changes over East Antarctica during the last climatic transition, Clim, Dyn, 23, 427-438, doi:10.1007/s00382-0040450-9.

Delmonte, B. et al. (2007), Late Quaternary Interglacials in East Antarctica from ice core dust records, in The Climate of Past Interglacials, Dev. Quat. Sci., vol. 7, edited by F. Sirocko et al., pp. 53-73, Elsevier, New York.

Fritz, S. C., et al. (2004), Hydrological variation during the last 170,000 years in the Southern Hemisphere tropics of South America, Quat. Res., 61, 95-104.

Gaiero, D. M. (2007), Dust provenance in Antarctic ice during glacial periods: From where in southern South America?, Geophys. Res. Lett., 34, L17707, doi:10.1029/2007GL030520.

Gaiero, D. M., et al. (2007), A uniform isotopic and chemical signature of dust exported from Patagonia: Rock sources and occurrences in southern environments, Chem. Geol., 238, 107-120.

Gaudichet, A., et al. (1992), Comments on the origin of dust in East Antarctica for present and ice age conditions, J. Atmos. Chem., 14, 129-142. Grousset, F. E., et al. (1992), Antarctic (Dome C) ice-core dust at 18 k.y. BP: Isotopic constraints and origins, Earth Planet. Sci. Lett., 111, 175182 . 
Prospero, J. M., P. Ginoux, O. Torres, S. E. Nicholson, and T. E. Gill (2002), Environmental characterization of global sources of atmospheric soil dust identified with the NIMBUS 7 Total Ozone Mapping Spectrometer (TOMS) absorbing aerosol product, Rev. Geophys., 40(1), 1002, doi:10.1029/2000RG000095.

Revel-Rolland, M., et al. (2006), Eastern Australia: A possible source of dust in East Antarctica Interglacial ice, Earth Planet. Sci. Lett., 249, $1-$ 13.

SiggaardAndersen, M.-L., et al. (2007), Soluble and insoluble lithium dust in the EPICA DomeC ice core: Implications for changes of the East Antarctic dust provenance during the recent glacial interglacial transition, Earth Planet. Sci. Lett., 258, 32-43.
Smith, J., et al. (2003), Isotopic constraints on the source of Argentinean loess with implications for atmospheric circulation and the provenance of Antarctic dust during recent glacial maxima, Earth Planet. Sci. Lett., 212, $181-196$.

R. J. Delmas and J.-R. Petit, Laboratoire de Glaciologie et Géophysique de l'Environnement, CNRS-Université Joseph Fourier, UMR 51230, BP 96, F38402 St Martin d'Hères Cedex, France. (delmas@lgge.obs.ujf-grenoble.fr; petit@lgge.obs.ujf-grenoble.fr)

B. Delmonte, DISAT, Department of Environmental Sciences, University Milano-Bicocca, Piazza della Scienza 1, I-20126 Milano, Italy. (barbara delmonte@unimib.it) 